\title{
Saker Falcon in the Biosphere State Nature Reserve "Askania-Nova" " Ukraine
}

\section{БАЛОБАН В БИОСФЕРНОМ ЗАПОВЕДНИКЕ «АСКАНИЯ-НОВА», УКРАИНА}

\author{
Lystopadsky M.A., Hofman O.P. (Biosphere State Nature Reserve "Askania-Nova", Ukraine) \\ Листопадский М.А., Гофман О.П. (Биосферный заповедник «Аскания-Нова» имени \\ Ф.Э. Фальц-Фейна НААН Украины)
}

Контакт:
Михаил Аистопачский
Биосферный
заповедник “Аскания-
Нова»
им. Ф.Э. Фальц-Фейна
НААН Украины
75230, Украина,
Херсонская обл.,
Чаплинский р-н,
Аскания-Hова,
ул. Фрунзе, 13
ekobirds@ukr.net

Contact:
Michail Lystopadsky
Biosphere State Nature
Reserve “Askania-Nova”
of the National Academy
of Agrarian Sciences
of Ukraine
Frunze str., 13
Askania-Nova,
Chaplinskiy
administrative region,
Kherson district,
Ukraine, 75230
ekobirds@ukr.net

Балобан (Falco cherrug Gray, 1834) - редкий охраняемый в Украине и на всей территории своего ареала виА (IUCN, 1996; Червона книга..., 2009; Фауна України:..., 2010; Карякин, 2013). Его относят к монгольскому типу фауны (Штегман, 1938), пустынно-горному фаунистическому комплексу (Белик, 2000), склерофильной эколого-фаунистической группировке (Белик, 2006; Милобог и Ар., 2010). В условиях современного степного юга Украины выцеляют две гнездовые группировки: первая приурочена к обрывам оз. Сиваш, вторая - лесостепная, гнездяшаяся преимушественно в лесных фррагментах степного и лесостепного кандшаста Украины (Милобог и мр., 2010). Несмотря на расположение заповедника между этими

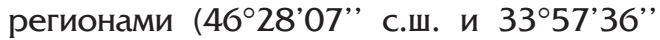
в.А.), балобан мия Аскании-Нова считаися очень редким видом, встречаюшимся только в осенне-зимний период (Гавриленко, Аистопацский, 2008).

В заповеднике, несмотря на давнюю историю орнитологических исследований

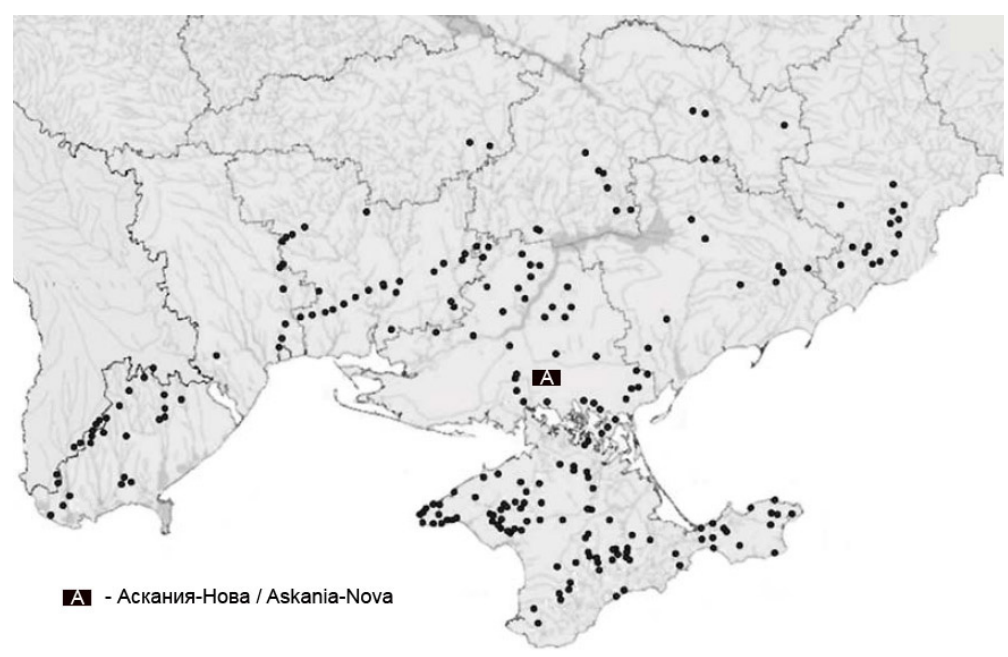

The first nesting of the Saker Falcon (Falco cherrug Gray, 1834) at the Reserve "Askania Nova” was marked by us in 2013. A nest located on a metal pole of power line $35 \mathrm{~kW}$ was found on May 16, 2013. The nesting structure was built by the Raven (Corvus corax Linnaeus, 1758).

There were three nestlings in the nest; two of them fledged successfully. Third nestling was found dead for unknown reasons in $03 / 06 / 2013$. His corpse had remained in the nest. The electric pole is located on the border between buffer and protected zones of the Reserve. An active sheep farm having a sizeable pasture, which is strongly devastated, is located to the east of it. This area is inhabited by a colony of the Little Ground Squirrel (Spermophilus pygmaeus Pallas, 1778).

The pasture is surrounded by several forest belts, where crows, Common Kestrels (Falco tinnunculus Linnaeus, 1758), Long-Legged Buzzards (Buteo rufinus Cretzschmar, 1827), etc. breed regularly. A protected steppe site "The Great Chapelsky Depression" enclosed with a metal wire fence is located in the west from the electric pole. About 500 wild individuals of several hoofed animal species are kept under semi-free conditions. This area has the traces of pascual digression (oppressed because of grazing). There is a pond constantly stocked

Рис. 1. Распространение балобана (Falco cherrug) в Украине и Мольове в начале XXI в. (по: Милобог и мp., 2010) и Аскания-Нова.

Fig. 1. Distribution of the Saker Falcon (Falco cherrug) in Ukraine and Moldova in the early $21^{\text {st }}$ century (Milobog et al., 2010) and location of the Askania-Nova. 
(с 1835 г.), этот вид впервые был отмечен в марте и декабре 1910 г., а также в марте 1915 г. (Треус, 1952). Затем, после значительного перерыва (Семёнов, Реут, 1989), отмечен вновь в 2002 и 2004 гг. на пролётах (Конспект ..., 2010).

Первый случай гнездования балобана на территории заповедника "АсканияНова" был отмечен нами в 2013 г. - 16 мая было обнаружено гнездо, которое располагалось на метамлической опо-

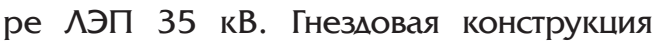
была построена вороном (Corvus corax Linnaeus, 1758), а в последуюшем занимамась пустельгой (Falco tinnunculus Linnaeus, 1758). В гнезде было три птенца, два из которых успешно стали на крыло. Третий птенец обнаружен погибшим по неизвестной причине 03.06.2013 г. Его труп так и оставался в гнезде. Опора АЭП с гнездом располагается на границе бусерной и заповедной зон заповедника. С востока от неё расположена действуюшая овцеводческая ферма со значительным по площали выгоном, растительность которого сильно сбитая. Аанная территория заселена колонией малого суслика (Spermophilus pygmaeus Pallas, 1778). Пастбише окаймлено несколькими лесными полосами, в которых регулярно гнездились ворон, обыкновенная пустельга, курганник (Buteo rufinus Cretzschmar, 1827) и мр. С запама от опоры АЭП располагается, огражАённый метамической сеткой, участок заповедной степи "Большой Чапельский поА". Там в полувольном состоянии удерживается около 500 особей Аиких копытных животных различных видов. Эта территория имеет следы пасквальной дигрессии. В центре участка располагается постоянно заполненный водоём. Наблюдения за взрослыми бамобанами показами, что они одинаково охотно используют как заповедную степь, так и пастбише. ОАнако корм (сусликов) чаше приносили с пастбиша. У основания опоры АЭП были найдены останки грача (Corvus frugilegus Linnaeus, 1758) (первостепенные маховые перья, кимь) и перья кольчатой горлицы (Streptopelia decaocto Frivaldszky, 1838). Следует заметить, что грачи в большом количестве собирамись в "киубы" на территории Большого Чапельского пода и формировами регулярное скопление на ночёвке в дендрологическом парке "Аскания-Нова", расположенном в 5 км от гнезда соколов.

Известно, что ворон является главным «поставшиком" гнёзА мля балобана в усмовиях степной Украины. Поэтому можно

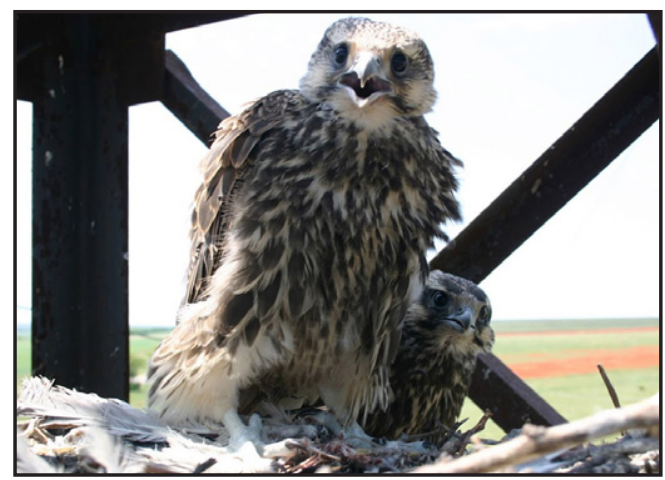

Птенцы в гнезде балобана (Falco cherrug) на ^ЭП, Украина. Фото М. Проммера.

Saker Falcon (Falco cherrug) nestlings in the nest on the power pole, Ukraine. Photo by M. Prommer.

in the center of the site. Observations of adult Saker Falcons showed that they used equally the protected steppe as well as the pasture.

However, food (sousliks) was brought more often from the pasture. At the foot of the electric pole remains of the Rook (Corvus frugilegus Linnaeus, 1758) (primary feathers, keel) and feathers of the Collared Dove (Streptopelia decaocto Frivaldszky, 1838) were found. It should be noted that a lot of rooks gathered at the Great Chapelsky Depression and formed regular congestion at the roosting time in the Dendrological Park "Askania Nova”, located $5 \mathrm{~km}$ from the nest of falcons.

It is known that the Raven is the main "supplier" of nests for Saker Falcons in the steppe of Ukraine. Therefore, we can assume that the increase of its number has a beneficial influence on colonization of electric poles by Saker Falcons. The Reserve "Askania Nova", as mentioned above, is inhabited by a large number of wild ungulates at the territory of one of the protected sites "The Great Chapelsky Depression”. The significant meltwater flooding was registered on this site in the winter-spring period in 2010. This has led to considerable mortality of animals that significantly increased the trophic value of these lands for ravens. The Great Chapelsky Depression was not flooded in subsequent years. Thus the death of animals was not occurred. As a result, a number of breeding ravens has decreased and some empty nests have appeared. Thus one of such abandoned nest constructions was occupied by a pair of Saker Falcons. 
полагать, что увеличение его численности благотворно влияет на расселение бамобана по опорам АЭП. В заповеднике «Аскания-Нова", как указывалось выше, на территории одного из заповеАныХ участков ("Большой Чапельский под") содержится большое количество Аиких копытных животных. В зимне-весенний период 2010 г. на территории этого участка отмечалось сушественное затопление талыми водами (Шаповая, Звегінцов, 2010), это, в свою очередь, привело к большому палежу животных, что значительно повысило трофическую ценность этих угодий мия ворона. В последуюшие годы затоплений Большого Чапельского пода не было и, соответственно, падежа животных не наблюдалось. Следствием этого было снижение численности ворона на гнездовании и появление свободных гнёзА. ОАна из освободившихся конструкций и была занята пустельгой, а впоследствии - и исследуемой парой балобанов.

Таким образом, группа фракторов (Аействуюший заповедный режим, наличие подходяших опор АЭП и пустых гнёзА ворона на них, намичие больших по плошади сбитых степных участков с колониями суслика, ночёвка грачей) способствоваяа успешному гнездованию балобана на территории заповедника. Это свидетельствует о потенциацьно высокой экологической ёмкости заповедника "Аскания-Нова" в отношении исследуемого вида.

Гнездование этих птиц и участившиеся их регистрации на пролёте могут говорить о тенденции увеличения численности украинской группировки балобанов в степной зоне Украины, что подтверждает более ранние выводы специаиистов (Милобог, 2012). Продолжаюшееся уплотнение гнезАОвой популяции происходит, по всей виАимости, благодаря "экологической переориентации" местных популяций в пользу скиерофильных представителей (Милобог и мр., 2010), что характерно и мия многих Аругих недавно вселившихся в "АсканиюНова" птиц (Листопацский, 2011).

Ввиду этого, на территории заповедника "Аскания-Нова" крайне необходимой является реализация биотехнических мероприятий мия улучшения условий гнезАования соколов на опорах высоковольтных

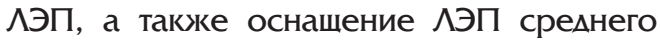
вольтажа птицезашитными устройствами мля нейтрамизации такого фактора, как гибель соколов от поражения электрическим током. В этой связи стоит указать, что, кроме бамобана, в заповеднике встре- чается не менее 16 видов хишных птиц, занесённых в последнее издание Красной книги Украины.

\section{Аитература}

Белик В.П. Птицы степного Придонья: формирование, антропогенная транссормация и вопросы охраны. Ростов-на- $\Delta$ ону: изАательство РГПУ, 2000. 376 с.

Белик В.П. Фауногенетическая структура авифрауны Памеарктики. - Зоологический журнаи, 2006. Т. 85. № 3. С. 298-316.

Гавриленко В.С., Аистопацский М.А. Аневные хишные птицы природных и транссормированных экосистем Биосферного заповедника "Аскания-Нова". - Хижі птахи України. Новітні Аослілження соколоподібних та сов / ред. В. М. Галушин и Ар.. Кривий Ріг, 2008. С. 73-78.

Карякин И.В. Балобан в Северной Евразии: прошлое, настояшее, а есть ки будушее? - Сохранение степных и полупустынных экосистем Евразии / С.А. Скияренко. Амматы, 2013. С. 40.

Гаврименко В.С., Аистопацський М.А., Полішук І.К., Ауменко В.П. Конспект фауни хребетних Біоссрерного заповідника "Асканія-Нова". Асканія-Нова, 2010. 120 с.

Аистопацский М.А. Фауногенетическая структура населения птиц дендросииьного комплекса Биоссерного заповедника "Аскания-Нова" и вероятные пути её формирования. - Мониторинг биоразнообразия экосистем Степной и Аесостепной зон / ред. А.А. Овчаренко. Бачашов, 2011. С. 91-94.

Мимобог Ю.В., Ветров В.В., Стригунов В.И., Белик В.П. Балобан (Falco cherrug Gray) в Украине и на сопредельных территориях. - Бранта, 2010. Вып. 13. С. 135-159.

Мимобог Ю.В. Соколообразные (Falconformes) Степной зоны Украины: видовой состав, территориальное распределение, цинамика численности и охрана. Авторесерат Аисс. канд. биол. наук. К. (Институт зоологии НАНУ), 2012. 28 c.

Семёнов Н.Н., Реут Ю.А. Фауна птиц и млекопитающих Биосрерного заповедника "Аскания-Нова". - Научно-технический бюметень УНИИЖ “Аскания-Нова", 1989. - Вып. 1. С. 43-47.

Треус B.А. Птицы района Аскании-Нова и методы их привлечения. - Аиссертация канд. биол. наук. Аскания-Нова, 1952. 226 с.

Годмевська О., Парнікоза І., Різун В., Фесенко Г., Куцоконь Ю., Загороднюк І., Шевченко М., Іноземцева $\Delta$. Фауна України: охоронні категорії. К., 2010. 80 с.

Червона книга України. Тваринний світ. / ред. І. А. Акімов. К.: Глобалконсаитинг, 2009. $600 \mathrm{c}$.

Шаповаи В.В., Звегінцов С.С. Еколого-гідро^огічний нарис паводку 2010 р. у Великому Чапельськоу поді. - Вісті Біосферного заповідника "Асканія-Нова", 2010. Т. 12. С. 33-55.

Штегман Б.К. Основы орнитогеографического деления Палеарктики. - Фауна СССР: Птицы, Т. 1. Ч. 2. М.-^.: издательство АН СССР, 1938. $157 \mathrm{C}$.

IUCN Red List of threatened animals Baillie J., Groombridge B. (Eds). Gland (Switzeland): IUCN, 1996. P. 378. 